\title{
Melamine-Ceramic Membrane for Oily Wastewater Treatment
}

\author{
M.E. Ossman ${ }^{1, *}$, W. Wagdy ${ }^{2}$, K.Y. Nabat ${ }^{3}$, A. Bramoo $^{3}$, Y. Mohamed ${ }^{3}$ and M. Gamal ${ }^{3}$ \\ ${ }^{1}$ City for Scientific Research and Technological Applications SRTA City, Borg Elarab, Alexandria, Egypt \\ ${ }^{2}$ Construction Engineering and Management, Faculty of Engineering, Pharos University, Alexandria, Egypt \\ ${ }^{3}$ Petrochemical Engineering Department, Faculty of Engineering, Pharos University, Alexandria, Egypt
}

\begin{abstract}
Four distinctive Ceramic membranes have been synthesized using bentonite and Egyptian clay with the expansion of melamine. The addition of melamine ( 1\% by wt.) enhanced the porosity, density, the thermal stability and water permeability of the membranes made from bentonite or Egyptian clay while decreasing the chemical stability of either bentonite or Egyptian clay membranes. The most noteworthy level of decrease in COD (94.7\%) is acquired for the concentration of $200 \mathrm{ppm}$ with saturating flux of $4.63 \mathrm{E}-05\left(\mathrm{~m}^{3} / \mathrm{m}^{2} . \mathrm{s}\right)$ utilizing $(B+M)$ membrane. The cost of the four manufactured clay membranes was assessed based on raw materials used in the present investigation.
\end{abstract}

Keywords: Oily water, emulsion, ceramic membrane, melamine.

\section{INTRODUCTION}

Oily wastewaters are one of the significant contaminants of the aquatic environment. Oily wastewater emitted to the aquatic environment is ranging from 0.5 to 1 ton for every 1 ton of processed oil from refineries [1]. As indicated by insights, consistently somewhere around 500 to 1000 million ton of oil is released into the aquatic environment through different ways [2], which causes water contamination, as well as ends up being a misuse of oil assets. And since the shortage of water resources has become more and more serious and due to the large volumes of oily wastewater generated by the petroleum refineries, petrochemical plants and transportation; oily wastewater treatment has turned into a pressing issue $[3,4]$.

During the previous years, different techniques have been reported in the literature for oily wastewater treatment, for example, adsorption $[5,6]$, flotation, coagulation [7, 8], chemical oxidation [9] and using of membranes [10]. Lately, regulations for the discharge of industrial wastewater has been changed. The new European regulations allow less than $10 \mathrm{mg} / \mathrm{L}$ of suspended solids, which could be met only using membrane technology [11]. Membrane separation technology for oily wastewater treatment offers numerous advantages with respect to other strategies, for instance, small footprint, low cost for establishing or operating and high oil removal efficiency [11, 12].

*Address correspondence to this author at the City for Scientific Research and Technological Applications SRTA City, Borg Elarab, Alexandria, Egypt; Tel: 20-1001392281; E-mail: mhr1410@hotmail.com
The utilization of porous ceramic membranes using low-cost materials has attracted much interest. Organic ceramic membrane technology has many disadvantages such as poor stability, poor acid and alkali corrosion resistance and non-renewable while Inorganic membrane has been studied and used by researchers due to its high-temperature resistance, high permeate flux, chemical corrosion resistance and good mechanical strength [13]. Many materials have been reported in the literature for the manufacture of ceramic membranes such as alumina $\left(\mathrm{Al}_{2} \mathrm{O}_{3}\right)$ [14], zirconia $\left(\mathrm{ZrO}_{2}\right)$ [15], titania $\left(\mathrm{TiO}_{2}\right)$ [16], silicon carbide ( $\mathrm{SiC})$ [17], glass $\left(\mathrm{SiO}_{2}\right)$ [18], or a combination of these metal oxides, and composites or combinations of oxides and non-oxides [19], as well as clay minerals (e.g., kaolin [20], mullite [21], dolomite [22], etc.). The thermally stable membrane expands the utilization area of membrane especially in comparing some crucial conditions. Elevated operation temperature is ready to improve membrane flux and decrease membrane fouling, which is meaningful for energy recovery and cost reductions [23]. Thermally stable membranes can be used in the treatment of various hot fluid streams without strict temperature control.

Melamine with triazine ring structure showed low toxicity, low reactivity and can endow the membrane with an excellent thermal resistance [24, 25]. The composite membrane prepared with melamine may show excellent thermal resistance and better chlorine resistance. Melamine is used for the first time to prepare TFC membranes with excellent thermal resistance and chlorine resistance and the composite NF membrane was successfully fabricated with the interfacial polymerization of melamine and TMC with the PEI UF membrane as substrate [24]. This research presented here focuses on preparing membranes from 
bentonite and Egyptian clay with the expansion of Melamine and study the effect of adding melamine on the thermal stability of the prepared membranes then apply the prepared membrane for efficient treatment of an oil-in-water emulsion. Then study the cost analysis for membranes based on raw materials.

\section{MATERIAL AND METHODS}

\subsection{Materials Used}

Bentonite; the EDAX analysis for bentonite is presented in Table 1, Egyptian Clay collected from Behaira Governorate area; the EDAX analysis for Egyptian clay is presented in Table 1, sodium carbonate, calcium carbonate, boric acid, sodium metasilicate and melamine as raw materials. All raw materials used for membranes fabrication were graded at least $99.5 \%$ pure and were used without any further purification.

\subsection{Preparation of the Membrane}

For the membrane preparation, Egyptian Clay or bentonite $(40.74 \mathrm{~g})$, sodium carbonate $(7.4 \mathrm{~g})$, boric acid $(3.71 \mathrm{~g})$, calcium carbonate $(18.52 \mathrm{~g})$ and sodium metasilicate $(5.52 \mathrm{~g})$ were blended together with $37.03 \mathrm{~g}$ of distilled water to yield a paste. Furthermore, for preparation of melamine bentonite $(B+M)$ and melamine clay $(C+M) ; 1 \mathrm{~g}$ of melamine were included. The pastes were then shaped like a round circle by utilizing a hardened steel 316 ring of $55 \mathrm{~mm}$ interior diameter across and $5 \mathrm{~mm}$ thickness. At that point, the circle compose shape was dried at room temperature for $24 \mathrm{~h}$, at $100^{\circ} \mathrm{C}$ for $12 \mathrm{~h}$ and at $250^{\circ} \mathrm{C}$ for $2 \mathrm{~h}$ for finish evacuation of moisture. In this manner, the membranes were sintered at $900^{\circ} \mathrm{C}$ for $5 \mathrm{~h}$ with a warming rate of $2^{\circ} \mathrm{C} / \mathrm{min}$. Subsequent to sintering, membranes turned out to be hard and unbending and with a permeable surface. The four membranes structure is displayed in Table 2. The four membrane discs were cleaned with rough paper to acquire a smooth, flat surfaces with a diameter of $52.5 \mathrm{~mm}$ and a thickness of $5 \mathrm{~mm}$.

\subsection{Characterization of the Membrane}

\subsubsection{Membrane Density and Porosity Measurements}

The Ceramic membrane discs were submerged in de-ionised water for $24 \mathrm{~h}$. Abundance water was wiped with tissue paper. The wet membrane discs were weighed. From that point onward, membrane discs were vacuum dried in an oven at $100^{\circ} \mathrm{C}$ once more. Membrane density was calculated using equation (1).

$\rho=\frac{m_{d r y}}{V}=\frac{m_{d r y}}{\frac{\pi}{4} d^{2} l}$

Where, $\rho$ is defined as density $\left(\mathrm{g} / \mathrm{cm}^{3}\right), m_{\text {dry }}$ as the weight of the dry ceramic disc, $d$ diameter of the membrane disc $(\mathrm{g})$ and $\mathrm{I}$ is the thickness of membrane disc.

membrane porosity, $\xi(\%)$ has been characterized as the volume of the pores over the aggregate volume of the permeable membrane disc. It typically is dictated by

Table 1: EDAX Analysis for Bentonite (B) and Egyptian Clay (C)

\begin{tabular}{|c|c|c|c|c|c|c|c|c|c|c|c|c|c|}
\hline Element & 0 & Mg & Al & Si & $\mathbf{S}$ & K & $\mathrm{Ca}$ & $\mathrm{Fe}$ & Co & C & $\mathrm{Na}$ & $\mathrm{Ti}$ & Total \\
\hline $\begin{array}{l}\text { Weight \% for } \\
\text { Bentonite (B) }\end{array}$ & 47.29 & 2.5 & 7.32 & 33.48 & 1.26 & 1.79 & 1.91 & 4.29 & 0.17 & ----- & ----- & ----- & 100 \\
\hline $\begin{array}{c}\text { Weight \% for } \\
\text { Egyptian Clay (C) }\end{array}$ & 42.17 & 2.41 & 7.73 & 20.04 & ---- & 0.99 & 5.15 & 10.86 & ---- & 8.36 & 1.13 & 1.15 & 100 \\
\hline
\end{tabular}

Table 2: The Membranes Compositions

\begin{tabular}{|c|c|c|c|c|c|c|c|c|c|}
\hline Membrane & Bentonite & Clay & $\begin{array}{l}\text { Calcium } \\
\text { Carbonate }\end{array}$ & $\begin{array}{l}\text { Sodium } \\
\text { Carbonate }\end{array}$ & $\begin{array}{l}\text { Boric } \\
\text { acid }\end{array}$ & $\begin{array}{c}\text { Sodium } \\
\text { Metasilicate }\end{array}$ & Melamine & Water & total \\
\hline B & $36 \%$ & ----- & $16.4 \%$ & $6.55 \%$ & $3.29 \%$ & $4.61 \%$ & --- & $32.79 \%$ & $100 \%$ \\
\hline C & ---- & $36 \%$ & $16.4 \%$ & $6.55 \%$ & $3.29 \%$ & $4.61 \%$ & ---- & $32.79 \%$ & $100 \%$ \\
\hline$B+M$ & $35.8 \%$ & --- & $15.8 \%$ & $6.5 \%$ & $3.26 \%$ & $4.57 \%$ & $0.88 \%$ & $32.5 \%$ & $100 \%$ \\
\hline $\mathrm{C}+\mathrm{M}$ & ----- & $35.8 \%$ & $15.8 \%$ & $6.5 \%$ & $3.26 \%$ & $4.57 \%$ & $0.88 \%$ & $32.5 \%$ & $100 \%$ \\
\hline
\end{tabular}


gravimetric strategy, considering the weight of water contained in the membrane pores, and it tends to be depicted by equation (2).

$\varepsilon=\frac{\Delta m}{V H 2 O} * 100=\frac{m_{w e t}-m_{d r y}}{\frac{\pi}{4} d^{2} l}$

\subsubsection{Water Permeability of the Membrane}

The permeation test (clean water flux) was done in a dead-end filtration setup. The permeability of the membrane, WP, was assessed from the inclines of the water flow through the membrane versus pressure diagram, as per the Hagen - Poiseuille equation, equation (3)

$J=W P \Delta P$

\subsubsection{Acid and Base Corrosion Test}

The chemical stability test of the membrane discs was tried in an acidic and alkaline arrangement. The orchestrated membrane discs were set independently in $\mathrm{HCl}$ and $\mathrm{NaOH}$ media for seven days. Toward the finish of test, the membranes were taken out from the solution (acid and alkaline), washed with distilled water, pruned with tissue paper to somewhat dry the discs, lastly dried in an oven at $100^{\circ} \mathrm{C}$ for around 60 minutes. From the distinction in the weight (previously, then after the treatment), the base and acid corrosion were determined.

\subsubsection{SEM Study}

The texture of the prepared ceramic membrane discs was investigated by SEM (Scanning Electron Microscope) to think about the surface morphology. SEM pictures from various segments of the membrane (and in various amplification) were contemplated.

\subsection{5. "Energy Dispersive X-Ray" EDAX Analysis for Ceramic Membranes Prepared}

EDX analysis of the membrane was carried out to verify the elemental composition of the membranes after adding melamine.

\subsubsection{FTIR Spectra of the Ceramic Membranes}

The surface functional groups and structure were studied by Fourier transform infrared spectroscopy (FTIR). The FTIR spectra of $\mathrm{C}, \mathrm{C}+\mathrm{M}, \mathrm{B}$ and $\mathrm{B}+\mathrm{M}$ ceramic membranes were recorded between 300 and 4,000 cm-1 using FTIR-8400S (Shimadzu Corporation, Nakagyo-Ku, Kyoto, Japan).

\subsubsection{Thermal Gravimetric Analysis (TGA) for the Ceramic Membranes}

Thermal Gravimetric Analysis or Thermogravimetric Analysis (TGA) were performed to measure the change of weight with respect to the increase in temperature in a controlled atmosphere to predict the thermal stability of the ceramic membranes.

\subsection{Experimental Set-Up}

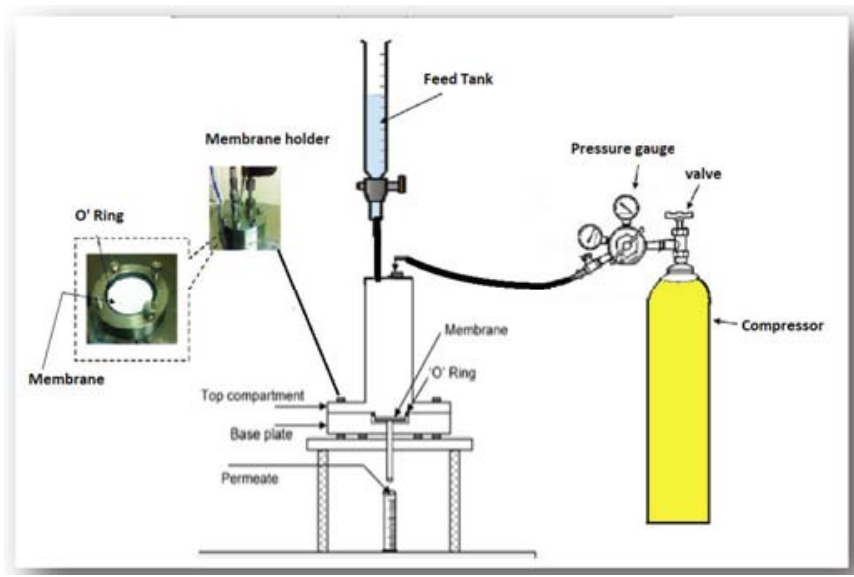

Figure 1: Experimental set up of oil filtration test.

\subsection{Microfiltration of Oil - in- Water Emulsion}

The oil filtration analyze was led with a simulated oil in water emulsion $(\mathrm{O} / \mathrm{W})$ of various oil concentrations $(100,150$ and $200 \mathrm{mg} / \mathrm{l})$ blended at $2000 \mathrm{rpm}$. The initial $10 \mathrm{ml}$ of the permeate was disposed of and time taken for the accumulation of the second $10 \mathrm{ml}$ of permeate was estimated for permeate flux calculations Figure 1. Every trial was conducted at room temperature $\left(25^{\circ} \mathrm{C}\right)$ and the rejection (R) was assessed by the accompanying articulations which represent the \% decrease in the COD esteem.

$$
R(\%)=\frac{C F-C p}{C F} * 100
$$

Where $C_{f}$ and $C_{p}$ are the oil concentration in the feed and permeate respectively.

The oil concentration in feed and permeated were evaluated using COD analysis.

\section{RESULTS AND DISCUSSIONS}

\subsection{Characterization of the Membrane}

\subsubsection{SEM Micrographs}

The SEM micrographs for the membrane are shown in Figures $\mathbf{2}$ and $\mathbf{3}$. Each membrane demonstrated a 


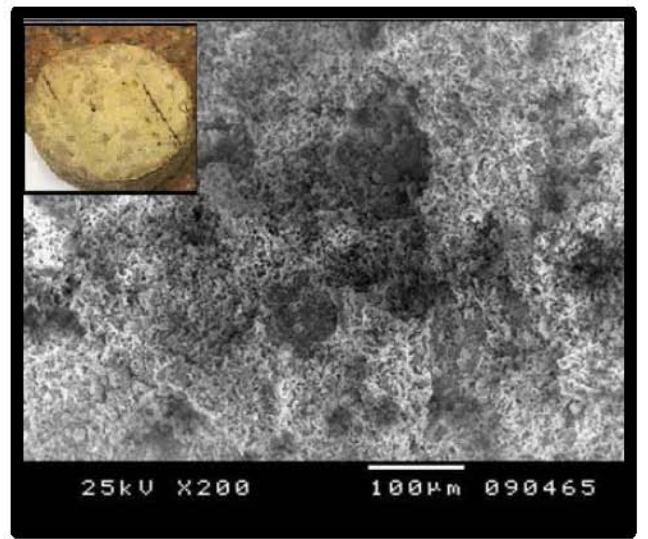

(a)

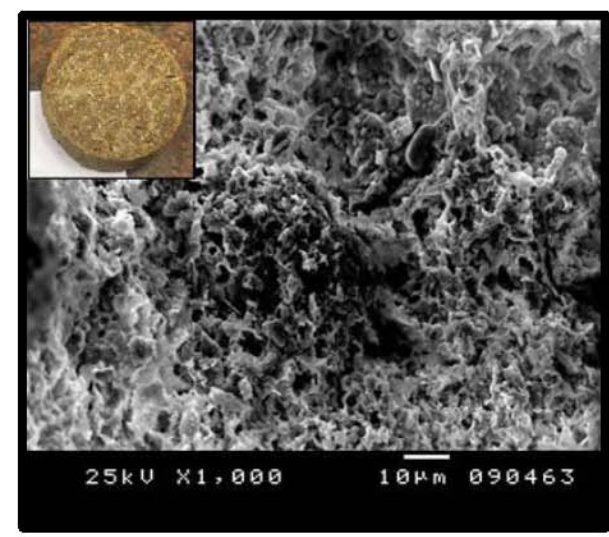

(b)

Figure 2: Membrane made of a) Egyptian clay (C) and b) Egyptian Clay and Melamine (C+M).

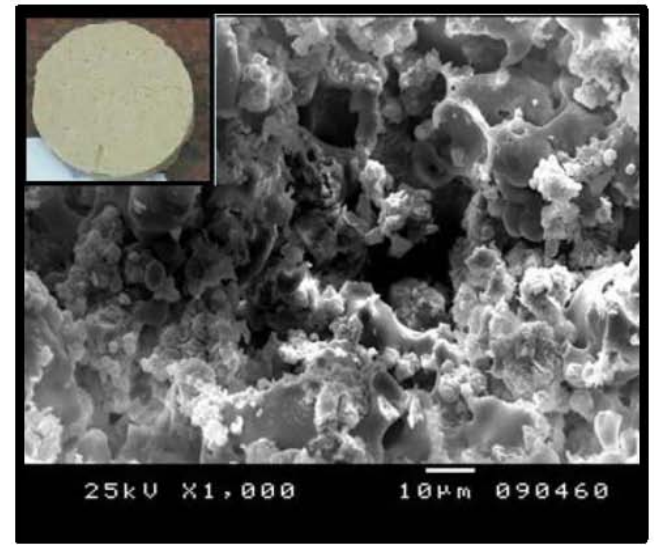

(a)

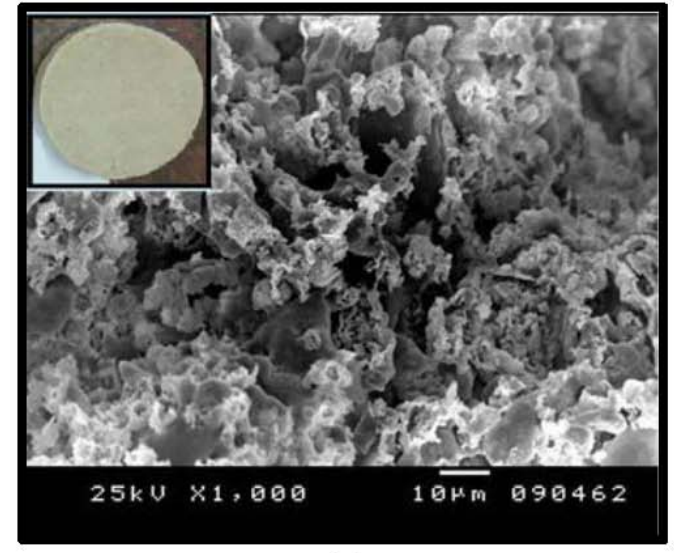

(b)

Figure 3: Membrane made of (a) Bentonite (B) and (b) Membrane made of Bentonite with Melamine $(B+M)$.

surface with rough morphological structure. A shallow perception of the SEM demonstrates that the membrane discs have extensively huge pore distance across and did not have any pinholes breaks or cracks. It tends to be observed that both bentonite and Egyptian clay membrane discs show an inhomogeneous surface. Truth be told it presents a few areas that don't contain any porosity and the obtained pores are not connected which would prompt a low penetrability of the membrane discs ( $C$ and $B$ only). But with the utilization of melamine, it was clear the growth of the porosity (for either $\mathrm{B}+\mathrm{M}$ or $\mathrm{C}+\mathrm{M}$ ). Likewise, the acquired pores were associated with one another. This clarifies the growth of the permeability for either bentonite with melamine membrane $(B+M)$ or Egyptian clay with melamine membrane $(C+M)$.

\subsubsection{EDAX Analysis for Ceramic Membranes Prepared}

To determine the composition of the membrane surface; the prepared membranes were analyzed using
EDX analysis. The results of the ceramic membranes surfaces compositions can be seen in Table 3. By comparing the composition of ceramic membranes prepared and the composition of raw materials used (showed in Table 1), it was found that new elements have appeared which are carbon $(\mathrm{C})$ and Nitrogen $(\mathrm{N})$ in the melamine bentonite $(B+M)$ and the $\%$ of $C$ increased in melamine clay $(\mathrm{M}+\mathrm{C})$ membranes due to adding $1 \mathrm{~g}$ melamine which is converted to carbon nitride $\mathrm{C}_{3} \mathrm{~N}_{4}$ after heating to $900^{\circ} \mathrm{C}$.

\subsubsection{FTIR Spectra of the Prepared Ceramic Membranes}

The observed bands showed in Figure 4 explained that most importantly, the characteristic bands for $B$, $\mathrm{B}+\mathrm{M}, \mathrm{C}$ and $\mathrm{C}+\mathrm{M}$ at 3945 and $3472 \mathrm{~cm}^{-1}$ have been shown to correspond, among others, basically $\mathrm{H}_{2} \mathrm{O}$ vibrations, indicating hydrous nature of the materials and presence of hydroxyl linkage. The bands observed for the materials at 2926, 2933 and $2934 \mathrm{~cm}^{-1}$ for $\mathrm{B}+\mathrm{M}$, $\mathrm{B}$ and $\mathrm{C}+\mathrm{M}$ respectively could be assigned to 
Table 3: EDAX Analysis for Ceramic Membranes Prepared

\begin{tabular}{|c|c|c|c|c|c|c|c|c|c|c|c|c|c|c|}
\hline Element & 0 & Mg & Al & Si & $\mathbf{S}$ & $\mathbf{K}$ & $\mathrm{Ca}$ & $\mathrm{Fe}$ & Co & C & $\mathrm{Na}$ & Ti & $\mathbf{N}$ & Total \\
\hline $\begin{array}{l}\text { Weight \% } \\
\text { for } B+M\end{array}$ & 27.68 & 2.11 & 3.16 & 26.3 & 0.46 & 0.63 & 18.77 & 2.4 & --- & 5.61 & 5.83 & -- & 7.05 & 100 \\
\hline $\begin{array}{l}\text { Weight \% } \\
\text { for } \mathrm{C}\end{array}$ & 32.51 & 2.19 & 4.28 & 25.39 & -- & --- & 14.57 & 8.32 & -- & 7.8 & 4.15 & 0.79 & -- & 100 \\
\hline $\begin{array}{l}\text { Weight \% } \\
\text { for } \mathrm{C}+\mathrm{M}\end{array}$ & 25.01 & 1.58 & 3.11 & 22.35 & -- & --- & 15.95 & 5.34 & --- & 11.63 & 2.96 & 0.53 & 10.54 & \\
\hline $\begin{array}{l}\text { Weight } \% \\
\text { for } B\end{array}$ & 36.24 & 2.46 & 4.48 & 25.74 & -- & --- & 22.52 & 2.54 & --- & -- & 6.11 & -- & --- & 100 \\
\hline
\end{tabular}
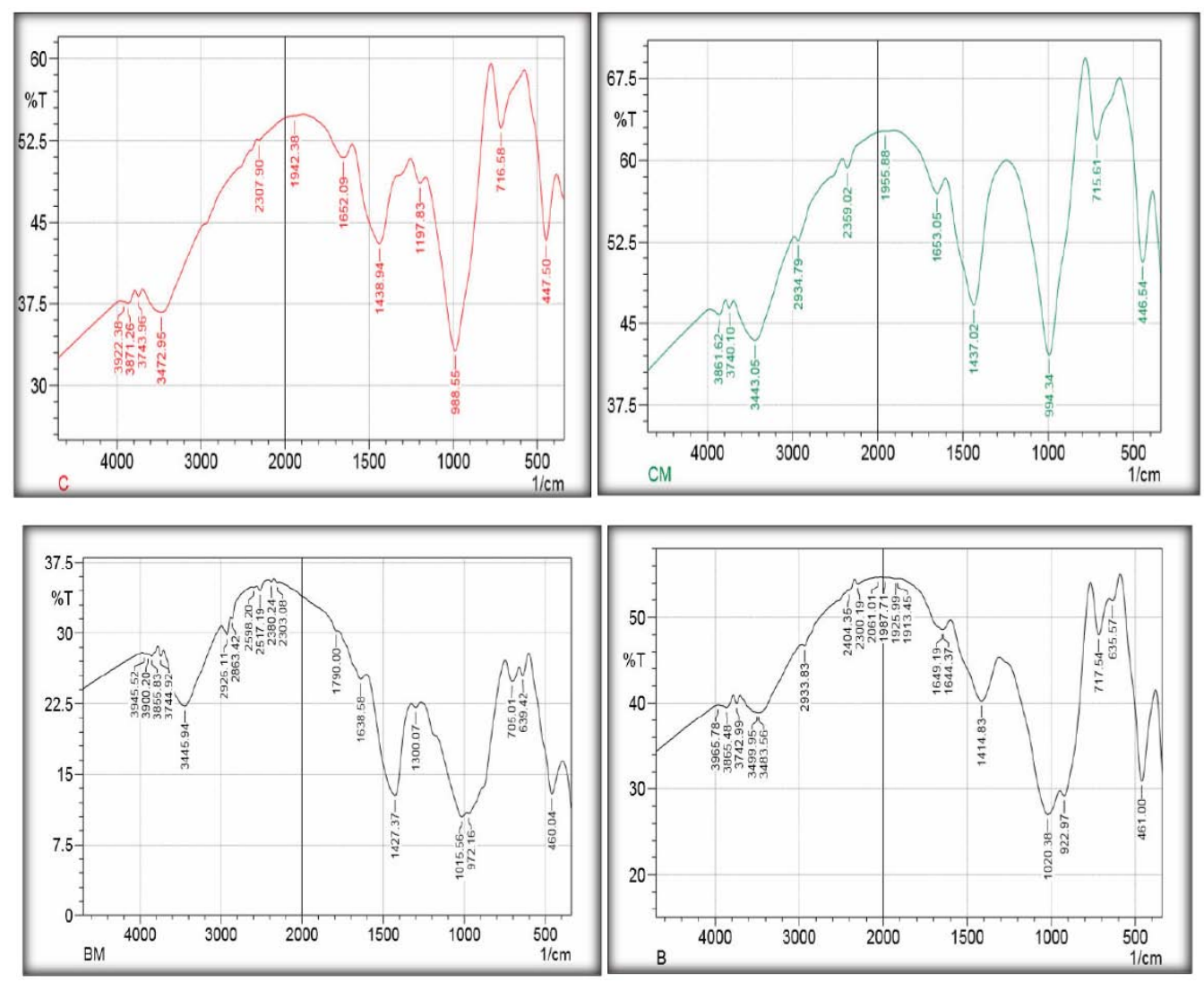

Figure 4: FTIR spectra of the ceramic membranes.

symmetrical stretch of $\mathrm{C}-\mathrm{H}$ mode of $-\mathrm{CH} 2$ - group. For the immediate range between 1638 and $1653 \mathrm{~cm}^{-1}$, the bending of water is observed. In the 1000 and $500 \mathrm{~cm}^{-1}$ regions, main functional groups were $\mathrm{Si}-\mathrm{O}$ and $\mathrm{Al}-\mathrm{OH}$. For the samples, well-resolved transmission bands are observed at $972,922,994$ and $988 \mathrm{~cm}^{-1}$ band which are within the range of the functional groups $\mathrm{Si}-\mathrm{O}$ and $\mathrm{Al}-$ $\mathrm{OH}$. The low transmission peaks exhibited from 718 to $635 \mathrm{~cm}^{-1}$ on samples $\mathrm{B}$ and $\mathrm{B}+\mathrm{M}$ are assigned $\mathrm{OH}$ deformation linked to $\mathrm{Al} 3+$ and $\mathrm{Mg} 2+$. Also the presence of the high-intensity broad doublet peak in the lower range of the transmission $700-1400 \mathrm{~cm}^{-1}$ mostly corresponding to $\mathrm{Si}-\mathrm{O}$ and $\mathrm{Al}-\mathrm{O}$ stretching modes [26]. The tetrahedral bending modes of Si-O, Si-
$\mathrm{O}-\mathrm{Mg}$ and $\mathrm{Si}-\mathrm{O}-\mathrm{Si}$ of the ceramic membranes occurred at 447,460 and $429 \mathrm{~cm}^{-1}$, respectively According to Srasra et al., 1994 [27].

\subsubsection{TGA for the Ceramic Membranes}

Figure 5 represents the TGA analysis for the prepared membranes. It merits referencing that the thermal analysis was carried out up to $1099^{\circ} \mathrm{C}$. During the main period of warming the mass loss of membranes ( $\mathrm{B}$ and $\mathrm{B}+\mathrm{M}$ ) up to $552^{\circ} \mathrm{C}$ and $622^{\circ} \mathrm{C}$ was $1.4 \%$ and $2.16 \%$ respectively while by increasing the temperatures up to $1099^{\circ} \mathrm{C}$, the $\mathrm{B}$ and $\mathrm{B}+\mathrm{M}$ membranes had indicated a mass loss of $6 \%$ and $5.8 \%$, respectively. 


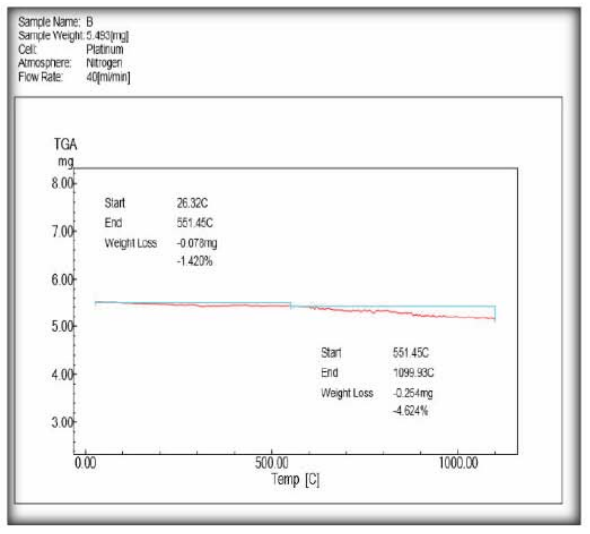

(a)

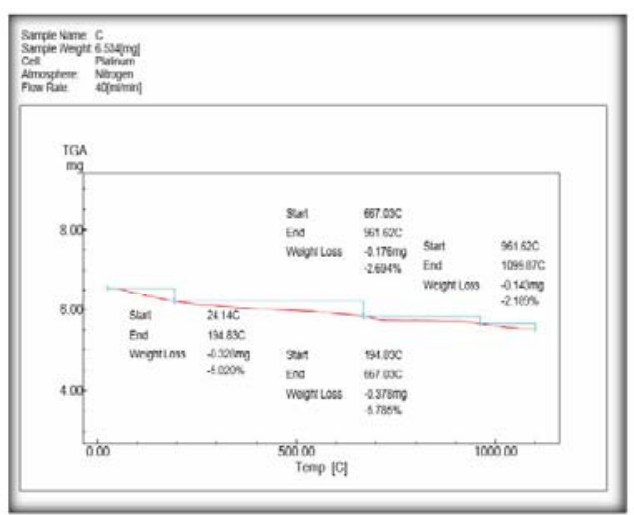

(c)

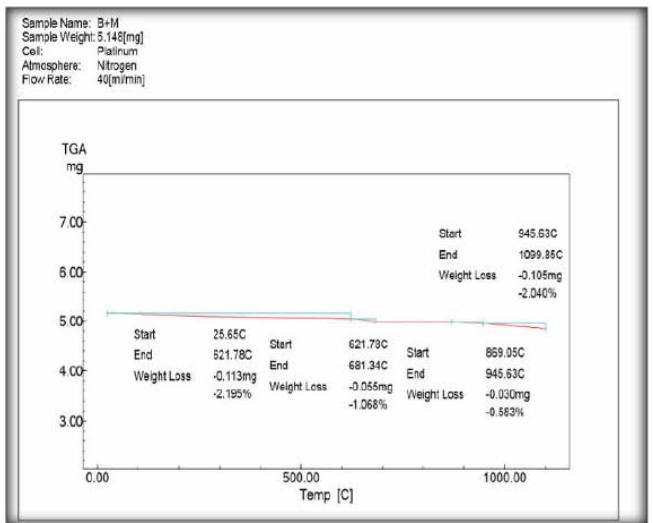

(b)

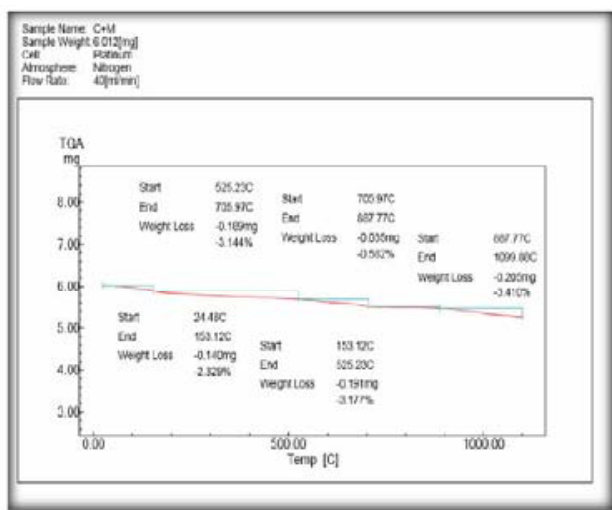

(d)

Figure 5: The TGA analysis for the prepared membranes (a) B, (b) B+M, (c) C and (d) C+M.

For $\mathrm{C}$ and $\mathrm{C}+\mathrm{M}$ membranes up to $1099^{\circ} \mathrm{C}$ the mass loss of $16 \%$ and $13 \%$ respectively. These mass losses can be explained to the loss of loosely bound water molecules and the presence of some absorbent substances (like $\mathrm{Na}$ metasilicate, boric acid). The results exhibit that the four types of membranes ( $B$, $\mathrm{B}+\mathrm{M}, \mathrm{C}$ and $\mathrm{C}+\mathrm{M})$ are thermally stable up to $1099^{\circ} \mathrm{C}$ and the membranes made of $B$ and $B+M$ are more thermal stable than that made of $\mathrm{C}$ and $\mathrm{C}+\mathrm{M}$ up to $1099^{\circ} \mathrm{C}$. The results also show that adding melamine increased the thermal stability for bentonite and Egyptian clay membranes.

\subsubsection{Membrane Density and Porosity}

Table 4 shows the density and porosity for the four fabricate membranes.
The data shown in Table 4 indicate that the membrane discs fabricated from Egyptian clay have higher density and porosity than the membrane disc fabricated from bentonite. Adding under $1 \%$ by weight to the blend used to fabricate either the bentonite or Egyptian clay membrane discs have expanded the density and porosity of the membrane discs.

\subsubsection{Acid and Base Corrosion Test}

Table 5 shows the effect of treating the four fabricated membrane discs $(\mathrm{B}, \mathrm{B}+\mathrm{M}, \mathrm{C}$, and $\mathrm{C}+\mathrm{M})$ to either acid or alkaline media to clarify the substance steadiness of the delivered membrane discs. The test is displayed by ascertaining weight reduction \% after subject the membrane discs to acid or alkaline media.

Table 4: Membrane Density and Porosity

\begin{tabular}{|c|c|c|c|c|}
\hline Property & B membrane & B+M membrane & C membrane & C+M membrane \\
\hline \hline Density $\left(\mathrm{g} / \mathrm{cm}^{3}\right)$ & 0.98 & 1.077 & 1.35 & 1.49 \\
\hline Porosity $(\%)$ & 50.22 & 54.08 & 53.66 & 57.43 \\
\hline
\end{tabular}


Table 5: Acid and Base Corrosion Test

\begin{tabular}{|c|c|c|c|c|}
\hline Test & B membrane & B+M membrane & C membrane & C+M membrane \\
\hline \hline Acid corrosion & 0 & 2.3 & 0 & 0.21 \\
\hline Base corrosion & 0.92 & 1.87 & 0.17 & 0.48 \\
\hline
\end{tabular}

Table 5 indicated that the membrane discs manufactured from either bentonite or Egyptian clay are stable in corrosive acid media. The membrane discs manufactured from either bentonite or Egyptian clay are marginally influenced by base media while the discs prepared from bentonite is higher influenced by base media than that prepared from Egyptian clay. Adding melamine to either Egyptian clay or bentonite will lessen the chemical stability of the membrane discs in either corrosive acid or base media.

\subsubsection{Water Permeability of the Membrane}

The four fabricated membrane discs were characterized by the assurance of water permeability. It tends to be seen that the water flux increases with increasing the applied pressure (Figures 6-9). Water permeability was resolved by the slope of the linear variation of flux $\left(\mathrm{m}^{3} / \mathrm{m} . \mathrm{s}\right)$ versus the applied pressure. Table 6 demonstrates the water permeability for the four fabricated membrane discs. The outcomes demonstrated that including melamine for either bentonite or Egyptian clay will upgrade the water permeability of the membrane discs.

Table 6: Water Permeability for the Fabricated Membrane Discs

\begin{tabular}{|c|c|c|}
\hline Membrane & WP $\left(\mathbf{m}^{3} / \mathbf{m}^{2} . \mathbf{s} \cdot\right.$ bar $)$ & $\mathbf{R}^{2}$ \\
\hline \hline$B$ & $3 \mathrm{E}-05$ & 0.948 \\
\hline $\mathrm{B}+\mathrm{M}$ & $4 \mathrm{E}-05$ & 0.947 \\
\hline$C$ & $4 \mathrm{E}-05$ & 0.882 \\
\hline $\mathrm{C}+\mathrm{M}$ & $5 \mathrm{E}-05$ & 0.888 \\
\hline
\end{tabular}

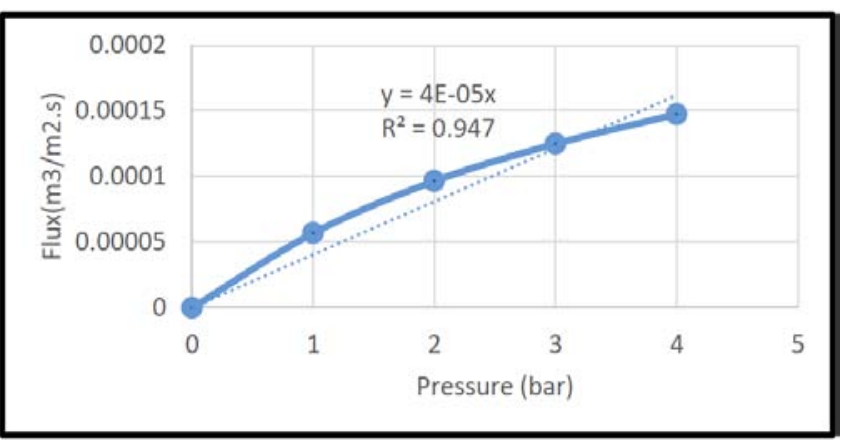

Figure 6: Water permeability for Bentonite + melamine $(B+M)$ membrane.

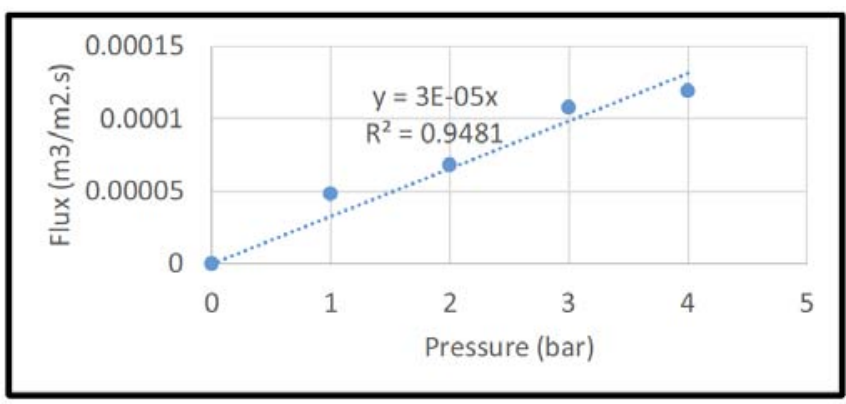

Figure 7: Water permeability for Bentonite membrane (B).

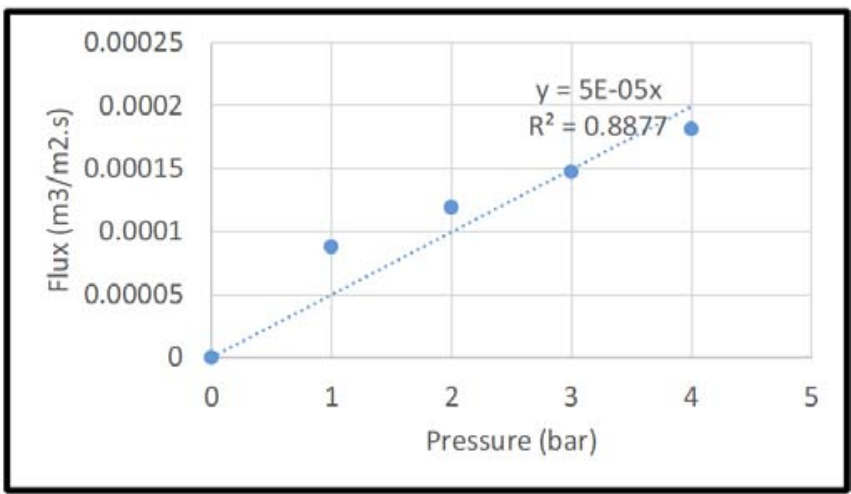

Figure 8: Water permeability for $(\mathrm{C}+\mathrm{M})$ membrane.

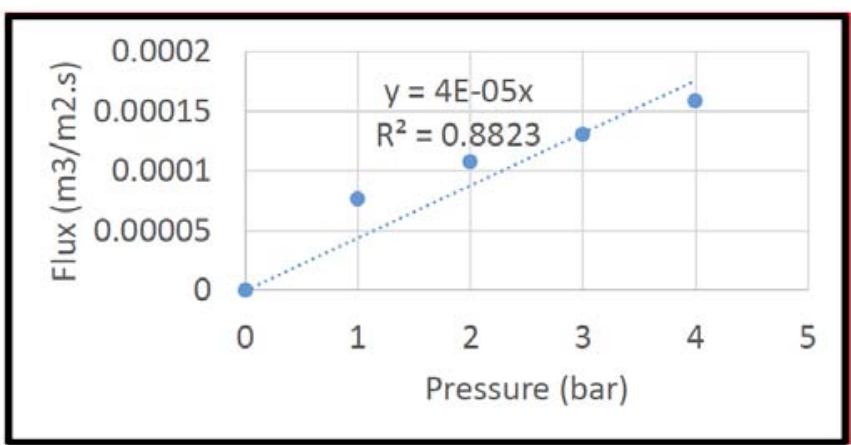

Figure 9: Water permeability for clay membrane (C).

\subsection{Application to the Treatment of Oily Wastewater}

The four fabricated ceramic membranes $(B, B+M$, $C$, and $C+M$ ) were connected for the treatment of simulated oily wastewater emulsions. Applied pressure, feed oil concentration and cross flow rates are the imperative factors that influence the treatment procedure as far as penetrate flux and dismissal. 


\subsubsection{Influence of Feed Concentration on Permeate Flux and Rejection}

Figures $10-13$ show the \% reductions in COD with time for various oil concentration $(100,150$, and 200 $\mathrm{ppm})$ for Bentonite (B), Bentonite with melamine $(B+M)$, Clay $(C)$ and Clay with melamine $(C+M)$ respectively. From the above-mentioned figures, it is clear that the $\%$ reduction in COD increases with increasing time and also the \% reduction in COD increases with increasing concentration. From the percentage of reduction in COD for the four fabricated membranes shown in Table 7 and Figure 14, the highest percentage of reduction in COD $(94.7 \%)$ is obtained for the oil feed concentration of $200 \mathrm{ppm}$ with permeate flux of $4.63 \mathrm{E}-05\left(\mathrm{~m}^{3} / \mathrm{m}^{2}\right.$. s) using $(B+M)$ membrane.

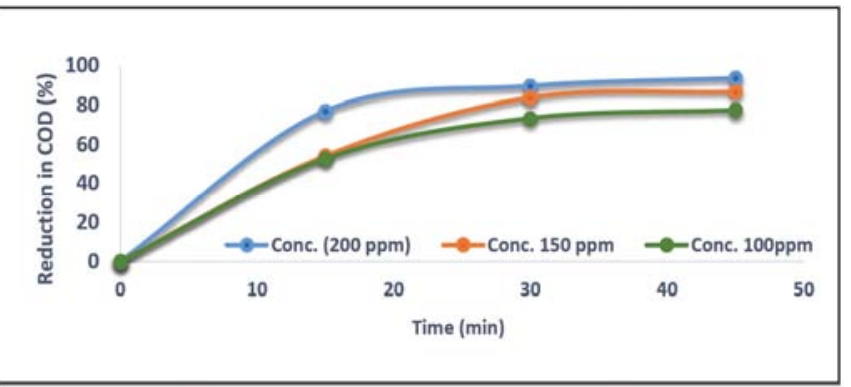

Figure 10: \% reduction in the COD of the samples for different oil concentration at 1 bar using $B$ membrane.

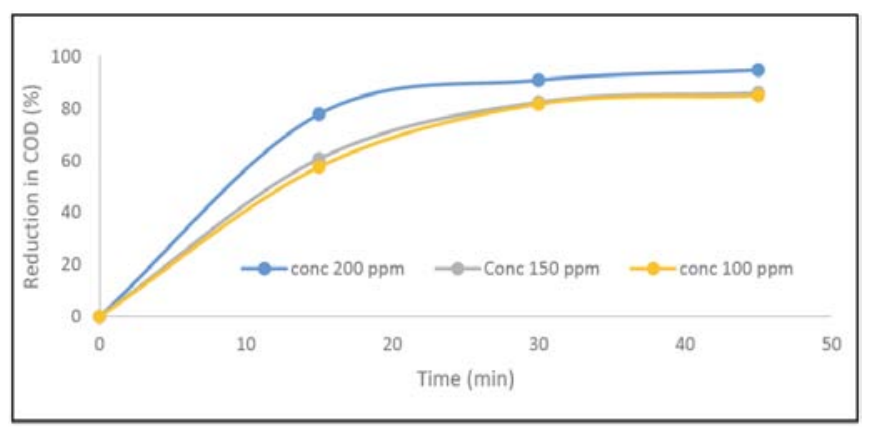

Figure 11: \% reduction in the COD of the samples for different oil concentration at 1 bar using $\mathrm{B}+\mathrm{M}$ membrane.

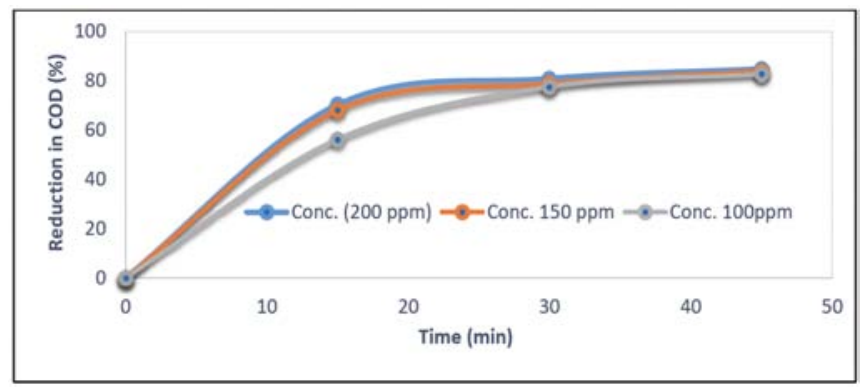

Figure 12: $\%$ reduction in the COD of the samples for different oil concentration at 1 bar using $\mathrm{C}$ membrane.

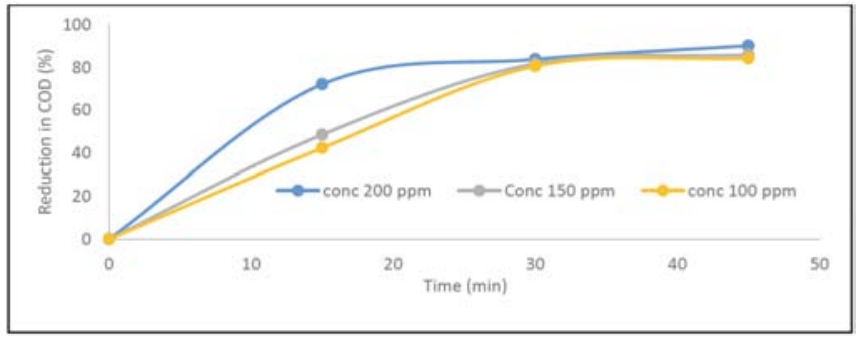

Figure 13: \% reduction in the COD of the samples for different oil concentration at 1 bar using $C+M$ membrane.

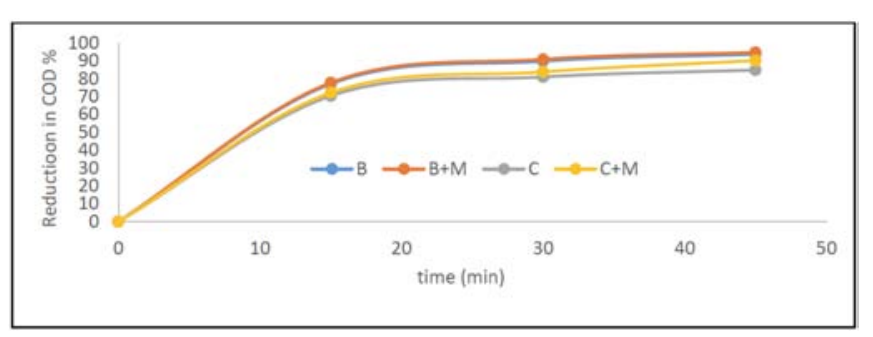

Figure 14: Comparison in the \% reduction of COD using the four fabricated membranes for $100 \mathrm{ppm}$ oil concentration and at 1 bar.

Table 7: \% Reduction in COD Using the Four Fabricated Membranes for 200 ppm Oil Concentration and at 1 Bar

\begin{tabular}{|c|c|c|}
\hline Membrane & \% reduction in COD (\%) & $\begin{array}{c}\text { Permeate flux } \\
\left(\mathbf{m}^{3} / \mathbf{m}^{2} . \mathbf{s}\right)\end{array}$ \\
\hline \hline C & 84.8 & $4.15 \mathrm{E}-05$ \\
\hline $\mathrm{C}+\mathrm{M}$ & 90.1 & $6.41 \mathrm{E}-05$ \\
\hline $\mathrm{B}$ & 93.64 & $3.69 \mathrm{E}-05$ \\
\hline $\mathrm{B}+\mathrm{M}$ & 94.7 & $4.63 \mathrm{E}-05$ \\
\hline
\end{tabular}

Figures 15-18 illustrate the permeate flux plots with time for various feed concentrations $(100,150$, and 200 $\mathrm{ppm}$ ) at an applied pressure of 1 . All figures clearly demonstrated that a higher concentration of oil prompts blend of oil droplets forming a greater droplet that outcome in higher COD removal. At the point when oil concentration increments from 100 to $200 \mathrm{mg} \mathrm{L}^{-1}$, the permeate flux decreases in light of the fact that the

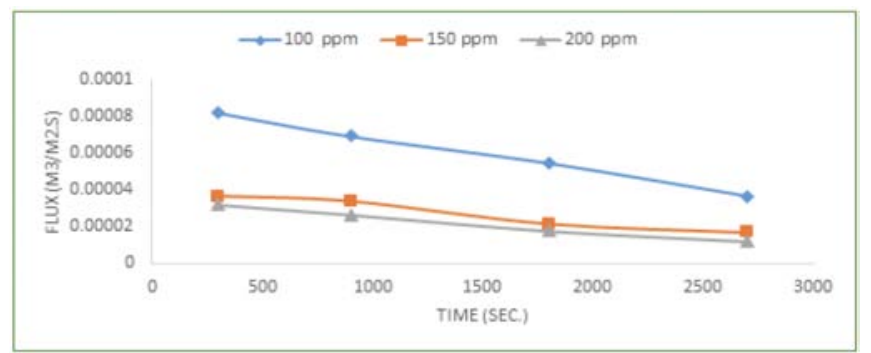

Figure 15: Variation of permeate Flux with time for different oil concentration at 1 bar using $B$ membrane. 
extent of oil droplets is higher than the pore distance across of the membrane at higher concentrations which agree with literature [28].

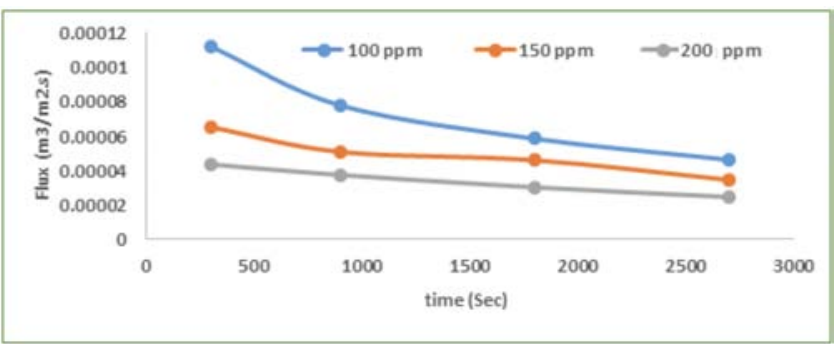

Figure 16: Variation of permeate Flux with time for different oil concentration at 1 bar using $B+M$ membrane.

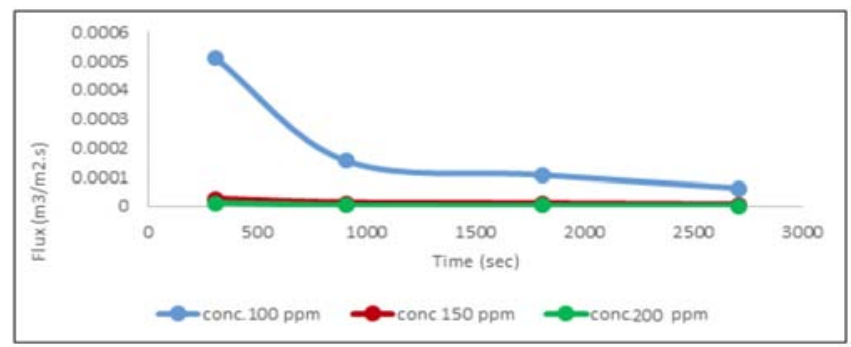

Figure 17: Variation of permeate Flux with time for different oil concentration at 1 bar using $\mathrm{C}$ membrane.

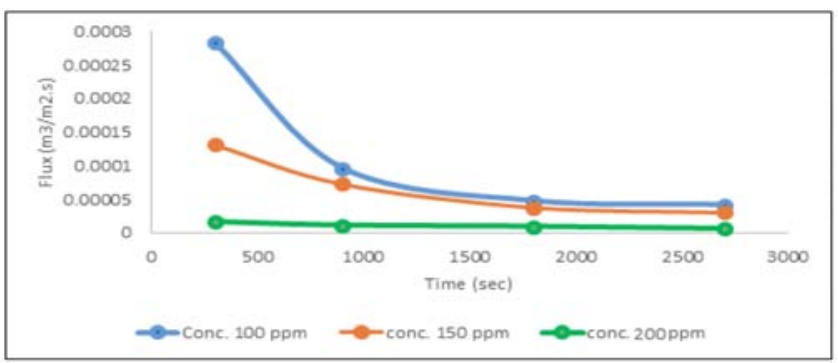

Figure 18: Variation of permeate Flux with time for different oil concentration at 1 bar using $\mathrm{C}+\mathrm{M}$ membrane.

The results showed that adding melamine for the membrane composition enhance both the \% reduction in COD and the permeate flux as shown in Figures 19, 20, and Table 7.

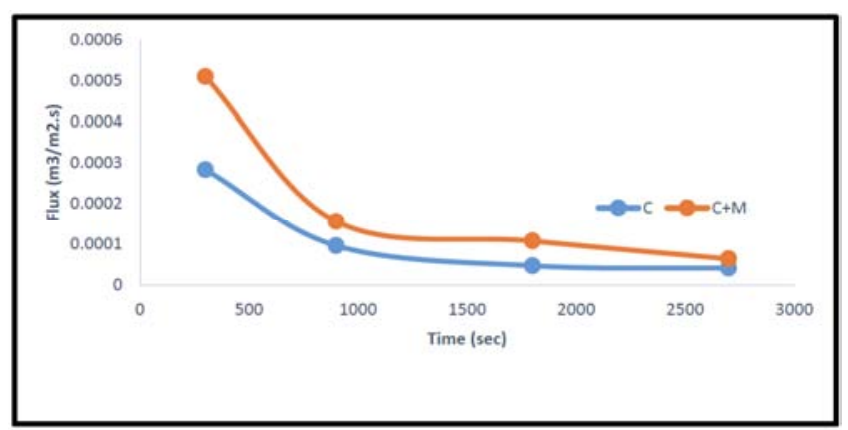

Figure 19: Comparison between variations of permeate Flux with time for oil concentration 200 ppm at 1 bar using $C$ and $\mathrm{C}+\mathrm{M}$ membrane.

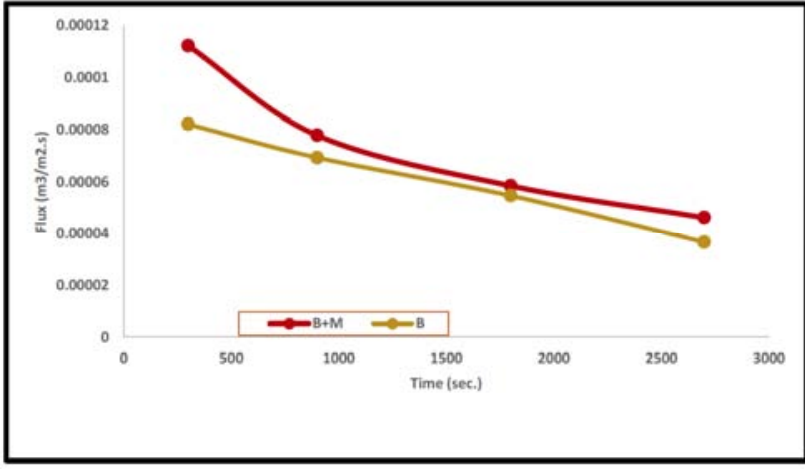

Figure 20: Comparison between variations of permeate Flux with time for oil concentration 200 ppm at 1 bar using $B$ and $B$ $+\mathrm{M}$ membrane.

\subsection{Effect of Backwashing in a Long-Term Operation}

Figure 21 shows the effect of backwashing on permeation flux decline, for the first $120 \mathrm{~min}$ of a longterm operation. Permeate flux was plotted as a function of time for $100 \mathrm{ppm}$ oil concentration at 1 bar. As watched, permeation flux was essentially reestablished by backwashing $[29,30]$. It may be seen that the backwash of the ceramic membranes with hot water is adequate to keep up its exhibition good for a long term activity. As appeared, it is conceivable to recuperate over $95 \%, 92 \%, 79 \%, 65 \%$, and $60 \%$ of the original flux by backwashing of $\mathrm{C}+\mathrm{M}, \mathrm{B}+\mathrm{M}, \mathrm{C}$ and $\mathrm{B}$ membranes respectively. It means that utilizing continuous backwashing expels oil and particulates that block the membrane pores and lessens penetrate permeate flux decline.

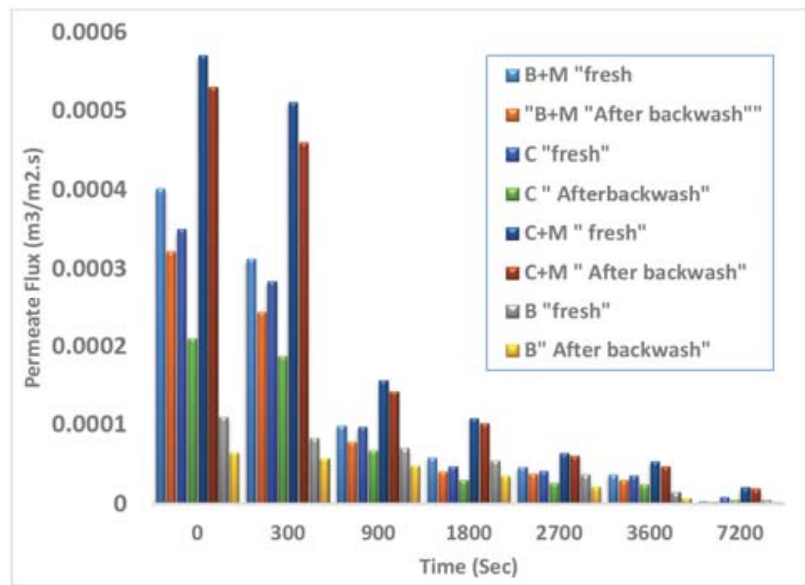

Figure 21: Effect of backwashing on flux decline (oil concentration $100 \mathrm{ppm}$ ).

\subsection{Cost Analysis for Membranes Based on Raw Materials}

The cost of the four fabricated ceramic membranes was evaluated on the basis of raw materials utilized in 
Table 8: Cost Analysis of the Raw Materials for Making One (B) Membrane

\begin{tabular}{|c|c|c|c|}
\hline Raw material & Unit price (L.E/kg) & $\begin{array}{c}\text { Material used for the } \\
\text { preparation of one membrane } \\
\text { (g) }\end{array}$ & $\begin{array}{c}\text { Cost of raw material used for } \\
\text { the preparation of one } \\
\text { membrane (LE.) }\end{array}$ \\
\hline \hline Bentonite & 320 & 40 & 12.8 \\
\hline Calcium carbonate & 48 & 18.52 & 0.876 \\
\hline Sodium carbonate & 30 & 7.4 & 0.222 \\
\hline Sodium metasilicate & 35 & 5.21 & 0.18 \\
\hline Boric acid & 70 & 3.71 & 0.26 \\
\hline \multicolumn{2}{r|}{ Total cost for raw materials used for the fabrication of (B)membrane } \\
(Round off value)
\end{tabular}

Table 9: Cost Analysis of the Raw Materials for Making One (B +M) Membrane

\begin{tabular}{|c|c|c|c|}
\hline Raw material & Unit price (LE. /kg) & $\begin{array}{c}\text { Material used for the } \\
\text { preparation of one membrane } \\
\text { (g) }\end{array}$ & $\begin{array}{c}\text { Cost of raw material used for } \\
\text { the preparation of one } \\
\text { membrane (LE.) }\end{array}$ \\
\hline \hline Bentonite & 320 & 40 & 12.8 \\
\hline Calcium carbonate & 48 & 18.52 & 0.876 \\
\hline Sodium carbonate & 30 & 7.4 & 0.222 \\
\hline Sodium metasilicate & 35 & 5.21 & 0.18 \\
\hline Boric acid & 70 & 3.71 & 0.26 \\
\hline Melamine & 900 & 1 & 0.9 \\
\hline \multicolumn{2}{|c|}{ Total cost for raw materials used for the fabrication of (B+M) membrane } \\
(Round off value)
\end{tabular}

Table 10: Cost Analysis of the Raw Materials for Making One (C) Membrane

\begin{tabular}{|c|c|c|c|}
\hline Raw material & Unit price (LE./kg) & $\begin{array}{c}\text { Material used for the } \\
\text { preparation of one membrane } \\
\text { (g) }\end{array}$ & $\begin{array}{c}\text { Cost of raw material used for } \\
\text { the preparation of one } \\
\text { membrane (LE.) }\end{array}$ \\
\hline \hline Egyptian Clay & 2 & 40 & 0.08 \\
\hline Calcium carbonate & 48 & 18.52 & 0.876 \\
\hline Sodium carbonate & 30 & 7.4 & 0.222 \\
\hline Sodium metasilicate & 35 & 5.21 & 0.18 \\
\hline Boric acid & 70 & 3.71 & 0.26 \\
\hline \multicolumn{2}{|c|}{ Total cost for raw materials used for the fabrication of (C)membrane } \\
(Round off value) & 2 \\
\hline
\end{tabular}

the present study (shown in Tables 8-11). The raw materials cost of the membranes per unit area is estimated to be 2439 L.E. $\left(136 \$ / \mathrm{m}^{2}\right)$ for (B) membrane, 2592 L.E. $\left(144 \$ / \mathrm{m}^{2}\right)$ for $(\mathrm{B}+\mathrm{M})$ membrane, 275 L.E. $\left(15 \$ / \mathrm{m}^{2}\right)$ for (C) membrane and 428 L.E. $\left(24 \$ / \mathrm{m}^{2}\right)$ for $(\mathrm{C}+\mathrm{M})$ membrane. In comparison with results in the literature, $\alpha$-alumina ceramic symmetric membranes cost approximately $\$ 500 / \mathrm{m}^{2}$ and symmetric stainless steel membrane costs approximately $\$ 3000 / \mathrm{m}^{2}$ [22]. Therefore, it can be concluded from the cost estimation that the prepared membrane is inexpensive as compared to alumina membranes. 
Table 11: Cost Analysis of the Raw Materials for Making One (C+M) Membrane

\begin{tabular}{|c|c|c|c|}
\hline Raw material & Unit price (LE./kg) & $\begin{array}{c}\text { Material used for the } \\
\text { preparation of one membrane } \\
\text { (g) }\end{array}$ & $\begin{array}{c}\text { Cost of raw material used for } \\
\text { the preparation of one } \\
\text { membrane (LE.) }\end{array}$ \\
\hline \hline Egyptian Clay & 2 & 40 & 0.08 \\
\hline Calcium carbonate & 48 & 18.52 & 0.876 \\
\hline Sodium carbonate & 30 & 7.4 & 0.222 \\
\hline Sodium metasilicate & 35 & 5.21 & 0.18 \\
\hline Boric acid & 70 & 3.71 & 0.26 \\
\hline Melamine & 900 & 1 & 0.9 \\
\hline \multicolumn{2}{|c|}{ Total cost for raw materials used for the fabrication of (C+M) membrane } \\
(Round off value)
\end{tabular}

\section{CONCLUSIONS}

Four Low-cost dead-end ceramic membranes have been effectively fabricated using inexpensive bentonite and Egyptian clay with the expansion of Melamine (adding less than $1 \%$ by weight melamine). The prepared membranes have been characterized by SEM, FTIR, EDAX, acid and base corrosion tests, water permeability and measuring density and porosity. The results indicating that utilization of melamine increasing the porosity, density, the thermal stability and water permeability of the membranes made from bentonite or Egyptian clay while decreasing the chemical stability of either bentonite or Egyptian clay membranes. The four membranes have been tested in the removal of oil from industrial water and the results showed that the highest percentage of reduction in $\operatorname{COD}(94.7 \%)$ is obtained for the feed concentration of $200 \mathrm{ppm}$ with permeate flux of $0.000128 \mathrm{~m} / \mathrm{s}$ using $(B+M)$ membrane. An increase in the oil concentration results in declines in permeate flux. The cost of the four fabricated ceramic membranes was evaluated on the basis of raw materials utilized in the present study. It can be concluded from the cost estimation that the prepared membranes are inexpensive as compared to alumina membranes. Overall, the presented work suggests the competency of the elaborated membranes in the direction of utilization towards the treatment of oily wastewater emulsion.

\section{REFERENCES}

[1] Painmanakul P, Sastaravet P, Lersjintanakarn S, Khaodhiar S. Effect of bubble hydrodynamic and chemical dosage on treatment of oily wastewater by Induced Air Flotation (IAF) process. Chem Eng Res Design 2010; 88(5-6): 693-702. https://doi.org/10.1016/j.cherd.2009.10.009

[2] Zhang MS, Zhu YH, Xiao Y, Wang ZY, Jia WL, Meng FW. Research Advance in Treatment of Oily Wastewater. China Resources Comprehensive Utilization 2007; 25(8): 22-24.
[3] Mueller J, Cen Y, Davis RH. Crossflow microfiltration of oily water. J Membr Sci 1997; 129: 221-235. https://doi.org/10.1016/S0376-7388(96)00344-4

[4] Madaeni SS, Monfared HA, Vatanpour V, Shamsabadi AA Salehi E, Daraei P, Laki S, Khatami SM. Coke removal from petrochemical oily wastewater using gamma-Al2O3 based ceramic microfiltration membrane. Desalination 2012; 293: 87-93.

https://doi.org/10.1016/j.desal.2012.02.028

[5] Li X, Liu J, Wang Y, Yijun H, Cao Y, Deng X. Separation of Oil from Wastewater by Coal Adsorption-Column Flotation. Separation Science and Technology 2015; 50(4): 583-591. https://doi.org/10.1080/01496395.2014.956759

[6] Fadali OA, Ebrahiem EE, Farrag TE, Mahmoud MS, El-Gamil A. Treatment of Oily Wastewater Produced from Refinery Processes Using Adsorption Technique. Minia Journal of Engineering and Technology (MJET) 2013; 32(1): 88-101.

[7] Li XB, Liu JT, Wang YT, Wang CY, Zhou XH. Separation of Oil from Wastewater by Column Flotation J China Univ Mining \& Technol 2007; 17(4): 0546-0551.

https://doi.org/10.1016/S1006-1266(07)60143-6

[8] Melo MV, Sant'anna GL Jr., Massarani G. Flotation techniques for oily water treatment. Environ Technol 2003; 24(7): 867-76. https://doi.org/10.1080/09593330309385623

[9] Kulik N, Trapido M, Veressinina Y, Munter R. Treatment of surfactant stabilized oil-in-water emulsions by means of chemical oxidation and coagulation. Environ Technol 2007; 28(12): 1345-1355 https://doi.org/10.1080/09593332808618896

[10] Madaeni SS, Gheshlaghi A, Rekabdar F. Membrane treatment of oily wastewater from refinery processes. AsiaPac J Chem Eng 2013; 8: 45-53. https://doi.org/10.1002/apj.1619

[11] Naidoo S, Olaniran AO. Treated Wastewater Effluent as a Source of Microbial Pollution of Surface Water Resources. Int J Environ Res Public Health 2013; 11(1): 249-270. https://doi.org/10.3390/ijerph110100249

[12] Cheryan M, Rajagopalan N. Membrane processing of oily streams. Wastewater treatment and waste reduction. J Membr Sci 1998; 151: 13-28. https://doi.org/10.1016/S0376-7388(98)00190-2

[13] Xiaoyuan D, Zhao W, Man X. Progress in Treatment of Oily Wastewater by Inorganic Porous Ceramic Membrane. MATEC Web of Conferences 2017; 114: 1-5. https://doi.org/10.1051/matecconf/201711402016

[14] Anderson MA, Gieselmann MJ, Xu Q. Titania and alumina ceramic membranes. J of Memb Sci 1988; 39(3): 243-258. https://doi.org/10.1016/S0376-7388(00)80932-1 
[15] Bouzerara F, Harabi A, Ghouil B, Medjemem N, Boudaira B, Condom S. Elaboration and Properties of Zirconia Microfiltration Membranes. Procedia Engineering 2012; 33: 278-284.

https://doi.org/10.1016/j.proeng.2012.01.1205

[16] Kujawa J, Cerneaux S, Koter S, Kujawski W. Highly Efficient Hydrophobic Titania Ceramic Membranes for Water Desalination. ACS Appl Mater Interfaces 2014; 6(16): 1422314230.

https://doi.org/10.1021/am5035297

[17] Zhou Y, Fukushima M, Miyazaki H, Yoshizawa Y, Hirao K, Lwamoto $Y$, Sato K. Preparation and characterization of tubular porous silicon carbide membrane supports. Journal of Membrane Science 2011; 369(1-2): 112-118. https://doi.org/10.1016/j.memsci.2010.11.055

[18] Hsieh HP. Materials and preparation of inorganic membranes. In: Membrane Science and Technology; Elsevier: Amsterdam, The Netherlands, 1996; Chapter 3: pp. 23-92. https://doi.org/10.1016/S0927-5193(96)80022-2

[19] Akbarnezhad S, Mousavi SM, Sarhaddi R. Sol-gel synthesis of alumina-titania ceramic membrane: Preparation and characterization. Indian Journal of Science and Technology 2010; 3(10): 1048-1051. https://doi.org/10.1115/1.4004311

[20] Jedidi I, Saïdi S, Khemakhem S, Larbot A, Elloumi-Ammar N, Fourati A, Charfi A, BenSalah A, BenAmar R. Elaboration of new ceramic microfiltration membranes from mineral coal fly ash applied to waste water treatment. Journal of Hazardous Materials 2009; 172 (1): 152-158. https://doi.org/10.1016/j.jhazmat.2009.06.151

[21] Bouzerara F, Harabi A, Achour S. Porous ceramic supports for membranes prepared from kaolin and doloma mixtures. Journal of the European Ceramic Society 2006; 26(9): 16631671. https://doi.org/10.1016/j.jeurceramsoc.2005.03.244

[22] Abbasi $M$, Mirfendereski M, Nikbakht $M$, Golshenas $M$, Mohammadi T. Performance study of mullite and mullitealumina ceramic MF membranes for oily wastewaters treatment. Desalination 2010; 259(1-3): 169-178. https://doi.org/10.1016/j.desal.2010.04.013
[23] Runlin H, Zhang S, Hu L, Guan S, Jian X. Preparation and characterization of thermally stable poly(piperazine amide)/PPBES composite nanofiltration membrane. J Membr Sci 2011; 370: 91-96.

https://doi.org/10.1016/j.memsci.2010.12.048

[24] Runlin H. Formation and characterization of (melamineTMC) based thin film composite NF membranes for improved thermal and chlorine resistances. Journal of Membrane Science 2013; 425-426: 176-181. https://doi.org/10.1016/j.memsci.2012.08.017

[25] Rangarajan R, Desai NV, Daga SL, Joshi SV, Prakash Rao A, Shah VJ, Trivedi JJ, Devmurari CV, Singh K, Bapat PS, Raval HD, Jewrajka SK, Saha NK, Bhattacharya A, Singh PS, Ray P, Trivedi GS, Pathak N, Reddy AVR. Thin film composite reverse osmosis membrane development and scale-up at CSMCRI, Bhavnagar. Desalination 2011; 282: 68-77.

https://doi.org/10.1016/j.desal.2011.09.003

[26] Mendioroz S, Pajares JA, Benito I, Pesquera C, Gonzalez F, Blanco C. Texture evolution of montmorillonite under progressive acid treatment: change from $\mathrm{H} 3$ to $\mathrm{H} 2$ type of hysteresis. Langmuir 1987; 3(5): 676-681.

\section{https://doi.org/10.1021/la00077a017}

[27] Srasra E, Bergaya F, Fripiat JJ. Infrared Spectroscopy Study of Tetrahedral and Octahedral Substitutions in an Interstratified Illite-Smectite Clay. Clays and Clay Minerals 1994; 42(3): 237-241. https://doi.org/10.1346/CCMN.1994.0420301

[28] Suresh K, Srinu T, Ghoshal AK, Pugazhenth G. Preparation and characterization of $\mathrm{TiO} 2$ and $\mathrm{y}-\mathrm{Al} 2 \mathrm{O} 3$ composite membranes for the separation of oil-in-water emulsions. RSC Adv 2016; 6: 4877-4888. https://doi.org/10.1039/C5RA23523E

[29] Lee S, Aurelle Y, Roques H. Concentration polarization, membrane fouling and cleaning in ultrafiltration of soluble oil. Journal of Membrane Science 1984; 19: 23-38. https://doi.org/10.1016/S0376-7388(00)80168-4

[30] Mugnier N, Howell JA, Ruf M. Optimisation of a back-flush sequence for zeolite microfiltration. Journal of Membrane Science 2000; 175: 149-161. https://doi.org/10.1016/S0376-7388(00)00412-9 